\title{
TRAINING COURSES
}

\section{Designed primarily for geoscientists from developing countries and run mainly on a post-graduate level. - Signifies first announcement in EPISODES.}

February 1986

METALLOGENY (Quito, Ecuador). Annual training course for Latin Americans organized by Central University of Quito, the Autonomous University of Madrid (Spain), and Unesco. Language: Spanish.

For Information: Ing. Antonio Salgado, Director, Curso Internacional de Metalogenia, Escuela de Ingenieria en Geologia, Minas y Petroleos, Division de Post-grado, Universidad Central, Quito, Ecuador.

February 1986 - March 1986

GEOCHEMICAL PROSPECTING TECHNIQUES (Tervuren, Belgium). Annual course sponsored by the Royal Museum of Central Africa and UNDP. Language: French.

For Information: Musée royal de l'Afrique centrale, Steenveg op Leuven, 13, B-1980 Tervuren, Belgium.

February 1986 - June 1986

MINERAL EXPLORATION (Leoben, Austria). Diploma course organized annually by the University of Mining and Metallurgy in Leoben and sponsored by Unesco. Language: English.

For Information: University for Mining and Metallurgy, Postgraduate course on mineral exploration, Montanuniversität, Leoben, A-8700, Austria.

February 1986 - December 1986

GEOTHERMICS (Pisa, Italy). Certificate course organized annually by the Istituto Internazionale per le Ricerche Geotermiche and sponsored by Unesco, UNDP and Italy. Language: Spanish.

For Information: Istituto Internazionale per le Ricerche Geotermiche, 1, Via Buongusto, 56100 Pisa, Italy.

March 1986 - April 1986

MINERAL EXPLORATION (Paris, France). Short course based on a simulation method organized annually by the Ecole Nationale Supérieure des Mines and sponsored by Unesco. Language: French.

For Information: Prof. H. Pélissonnier, Ecole des Mines, $60 \mathrm{Bd}$ Saint Michel, 75272 Paris, Cedex 06 , France.

March 1986 - April 1986

STRUCTURAL GEOLOGY (Dehra Dun, India) Regional training course organized by Wadia Institute of Himalayan Geology and sponsored by Unesco.

For Information: Dr. V.C. Thakur, Wadia Institute of Himalayan Geology, Dehra Dun - 248001, India.

March 1986 - November 1986

PHOTOINTERPRETATION APPLIED TO GEOLOGY AND GEOTECHNICS (Bogota, Colombia). Diploma course organized by the Centro Interamericano por Fotointerpretacion (CIAF) in cooperation with ITC and Unesco. Language: Spanish.

For Information: Academic Secretariat of the CIAF, Apartado Aereo 53754, Bogota 2, Colombia.

April 1986 - July 1986

RURAL GROUNDWATER DEVELOPMENT (Loughborough, U.K.). A 10 -week diploma course organized annually by WEDC.

For Information: WEDC, University of Technology, Loughborough LEIl 3TU, U.K.
May 1986 - June 1986

GEOPHYSICS APPLIED TO GEOTHERMAL PROSPECTION (Manizales, Colombia). Annual course organized for Latin Americans by the Latin American Organization for Energy with financial assistance from Unesco. Language: Spanish.

For Information: Organizacion Latinoamericant de Energia (OLADE), P.O. Box 119, Quito, Ecuador.

May 1986 - June 1986

- BASE MAPPING TECHNIQUES (Washington, D.C., U.S.A.). A training course organized by the U.S. Geological Survey for foreign participants in the preparation, publication, and use of base maps. For Information: U.S. Geological Survey, Training Section, National Center (917), Reston, Virgina 22092 , U.S.A.

June 1986 - August 1986

TECHNIQUES OF HYDROLOGIC INVESTIGATIONS (Washington, D.C. and Denver, Colorado, U.S.A.). Annual training course for international participants.

For Information: Office of International Hydrology, Water Resources Division, U.S. Geological Survey, 470 National Center, Reston, Virginia 22092 , U.S.A.

July 1986 - August 1986

SUMMER COURSE ON EARTH SCIENCES: CRYSTALLOGRAPHY, MINERALOGY, METALLOGENY (Madrid, Spain). Annual course organized by the Department of Geology and Geochemistry of the Universidad Autonoma de Madrid and sponsored by Unesco. Language: Spanish.

For Information: Prof. T. Monseur, Departamento de Geologia y Geoquimica, Facultad de Ciencias, Universidad Autonoma de Madrid, Canto Blanco, Madrid 34, Spain.

July 1986 - September, 1986

VOLCANOLOGY (Quito, Ecuador). Annual 10week course organized for Latin Americans by the Latin American Organization for Energy with financial assistance from Unesco. Language: Spanish.

For Information: Organizacion Latinoamericana de Energia (OLADE), P.O. Box 119, Quito, Ecusdor.

August 1986 - June 1988

SOIL SCIENCE AND WATER MANAGEMENT (Wageningen, The Netherlands). Two-year M.Sc. course designed for B.Sc. graduates from developing countries. Language: English.

For Information: Director of Studies of the M.Sc. course in Soil Science and Water Management, P.O. Box 37, 6700 AA Wageningen, The Netherlands.

September 1986 - October 1986

REMOTE SENSING: FUNDAMENTALS OF APPLICATIONS AND ANALYSIS TECHNIQUES, 25th International Workshop. (Sioux Falls, South Dakota, U.S.A.). Program of training workshops organized by the U.S. Geological Survey for non-U.S. scientists, engineers, and resources managers.

For Information: Training section, Office of International Geology, U.S. Geological Survey, National Center (917), Reston, VA 22092, U.S.A.
September 1986 - October 1986

- GEOLOGIC AND HYDROLOGIC HAZARDS (Denver, Colorado, U.S.A.). A training program organized by the U.S. Geological Survey for international participants from disaster-prone countries.

For Information: U.S. Geological Survey, Training Section, 917 National Center, Reston, Virginia 22092, U.S.A.

September 1986 - November 1986

DRILLING OF GEOTHERMAL WELLS (Mexicali, Mexico). Annual 12-week seminar organized for Latin Americans by the Latin American Organization for Energy with financial assistance from Unesco. Language: Spanish.

For Information: Organizacion Latinoamericana de Energia (OLADE), P.O. Box 199, Quito, Ecuador.

September 1986 - November 1986

GEOTHERMAL RESERVOIR ENGINEERING (Mexicali, Mexico). Annual 9-week course organized for Latin Americans by the Latin American Organization for Energy with financial assistance from Unesco. Language: Spanish. For Information: Organizacion Latinoamericane de Energia (OLADE), P.O. Box 119, Quito, Ecuador.

September 1986 - November 1986

GEOTHERMAL ENERGY (Kyushu, Japan). Annual short course organized by the Government of Japan and sponsored by Unesco. Language: English.

For Information: Japan International Cooperation Agency (2nd Training Division, Training Affairs Department), P.O. Box 216, Shinjuku Mitsui Building, 2 - 1, Nishi-shinjuku, Shinkuku-ku, Tokyo 160, Japan.

September 1986 - June 1987

REMOTE SENSING TRAINING (Toulouse, France). A diploma course with options for geoscientists sponsored by the French Aerospace Remote Sensing Development Organization (GDTA), BRGM, IFP and other French institutions. Language: French.

For Information: GDTA-Formation, 18 avenue Edouard-Belin, 31055 Toulouse Cedex, France.

September 1986 - August 1987

MINING EXPLORATION AND EXPLORATION GEOPHYSICS (Delft, The Netherlands). Annual diploma courses organized by the International Institute for Aerial Survey and Earth Sciences and sponsored by Unesco. Language: English.

For Information: ITC (ME), 3, Kanaalweg, 2628 Delft, The Netherlands.

October 1986 - November 1986

TECTONICS, SEISMOLOGY AND SEISMIC RISK ASSESSMENTS (Potsdam, East Germany). One-month training course organized annually by East German Academy of Sciences in collaboration with Unesco. Language: English.

For Information: Prof. Dr. H. Kautzleben, Director, Central Earth's Physies Institute, Academy of Sciences of the German Democratic Republic, Telegraphenberg, DDR 1500 Postdam, German Democratic Republic.

October 1986 - July 1987

- FNGINEERING HYDROLOGY (Gaiway, Ireland). Annual diploma and post-graduate courses organized by the Department of Engineering Hydrology, University College Galway, Ireland. Sponsored by Unesco-IHP and the world Meteorological Organization.

For Information: Prof. J.E. Nash, Department of Engineering Hydrology, University College Galway, Galway, Ireland.

October 1986 - September 1987

WATER AND WASTE ENGINEERING FOR DEVELOPING COUNTRIES (Loughborough, England, U.K.). Twelve-month MSe programme organized annually for engineers and scientists from developing countries by WEDC. 


\section{Training Courses}

For Information: John Pickford, WEDC Group Leader, University of Technology, Loughborough, Leies LE11 3TU, U.K.

October 1986 - September 1987

FUNDAMENTAL AND APPLIED QUATERNARY GEOLOGY (Brussels, Belgium). Annually organized training course leading to a Master's degree in Quaternary Geology by the Vrije Universiteit Brussel (IFAQ) and sponsored by Unesco. Languages: English and French.

For Information: Prof. Dr. R. Paepe, Director of IFAQ, Kwartairgeologie, Vrije Universiteit Brussel, Pleinlaan 2, B-1050, Brussels, Belgium.

October 1986 - September 1987

HYDRAULIC ENGINEERING AND HYDROLOGY (Delft, The Netherlands). Diploma courses organized annually by the International Institute for Hydraulic and Environmental Engineering and sponsored by Unesco for professionals from developing countries. Language: English.

For Information: International Institute for Hydraulic and Environmental Engineering (IHE), Oude Delft 95, P.O. Box 3015, 2601 DA Delft, The Netherlands.

November 1986 - December 1986

REMOTE SENSING APPLICATIONS COURSE FOR EARTH SCIENCES (Enschede, The Netherlands). Annual course organized by International Institute for Aerial Survey and Earth Sciences and sponsored by Unesco. Language: English.

For Information: ITC Student Registration Office, P.O. Box 6, 7500 AA Enschede, The Netherlands.

November 1986 - December 1986

SMALL MINE POTENTIAL AND TECHNOLOGY (Leoben, Austria). Annual training course sponsored by Austria and Unesco. Language: English.
For Information: Prof. Wolfbauer, Forschungsgesellschaft Joanneum, Roseggerstrasse 15, A-8700 Leoben, Austria.

November 1986 for two 11-month sessions ENGINEERING GEOLOGY (Delft, The Netherlands). New post-graduate diploma course leading to M.Sc. degree in Engineering Geology.

For Information: ITC Student Registration Office, P.O. Box 6, 7500 AA Enschede, The Netherlands.

December 1986 - January 1987

METHODS AND TECHNIQUES IN EXPLORATION GEOPHYSICS (Hyderabad, India). Diploma course organized annually by the National Geophysical Research Institute of the Council of Scientific and Industrial Research, Hyderabad, India, and sponsored by Unesco. Language: English.

For Information: The Director, International Training Course on Methods and Techniques in Geophysical Exploration, National Geophysical Research Institute, Hyderabad, 500007 (A.P.) India.

January 1987 - April 1987

DIGITAL IMAGE PROCESSING (Enschede, The Netherlands). Certificate courses on techniques for national resources surveys, organized annually by the International Institute of Aerial Surveys and Earth Sciences (ITC). Sponsored by Unesco. Language: English.

For Information: ITC Student Affairs Office, P.O. Box 6, 7500 AA Enschede, The Netherlands.

\section{May 1987 - November 1987}

GENERAL HYDROLOGY with emphasis on groundwater (Argentina). Post-graduate course organized every other year and sponsored by Unesco. Language: Spanish.

For Information: Comité Nacional para el
Programa Hidrologico Internacional de la Republica Argentina, Av 9 de Julio 1925 - $15^{\circ}$ piso, 1332 Buenos Aires, Argentina.

August 1987 - October 1987

GEOCHEMICAL PROSPECTING METHODS (Prague, Czechoslovakia). Certificate course organized every second year by the Geologica Survey of Czechoslovakia and sponsored by Unesco, IAGC and Czechoslovakia. Language: English.

For Information: GEOCHIM Unesco CSSR, Geological Survey of Prague, Malostranské nam. 19, 11821 Prague 1, Czechoslovakia.

September 1987 - October 1987

GROUNDWATER TRACING TECHNIQUES (Graz, Austria). Five-week course organized every other year by the Institute of Technical Geology, Petrography and Mineralogy and sponsored by Unesco. Language: English.

For Information: Institute of Technical Geology, Petrography and Mineralogy of the University of Technology, A-8010 Graz, Austria.

\section{OTHER TRAINING PROGRAMS}

- DESERT STUdIES (Negev, Israel). Courses, seminars and workshops in Desert Hydrology and related topies organized by The Blaustein International Center for Desert Studies, Negev, Israel.

For Information: Prof. Arie Issar, Chairman of the Water Resources Center, The Blaustein International Center for Desert Studies, Ben-Gurion University of the Negev, Sede-Boger Campus, Negev, Israel.

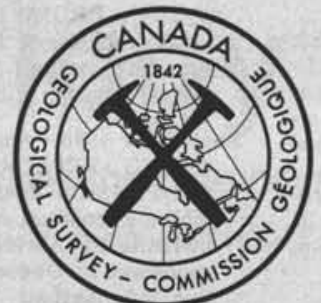

THE GEOLOGICAL SURVEY OF CANADA

Memoirs, Bulletins, Papers Geological, Geophysical and Geochemical maps Indexes, on-line databases SERVING CANADIAN
GEOSCIENCE SINCE 1842
Recent Publications

- Destructive mass movements in high nountains hazard and management; G.H. Eísbácher and J.J. Clague; Paper $84-16$

- Canadian mineral deposit types: a geological synopsis; O.R. Eckstrand, ed., Economic Gelogy Repoit 36

- Quaternary stratigraphy of Canada - a Canadian contribution to, IGCP Project 24; R.J. Fulton, ed., Paper $84 \div$

- Index to Geological Survey of Canada publications from 1980 to 1984

The Trias and its ammonoids: the evolution of a time scale; E.T. Tozer, Miscellaneous Report 35
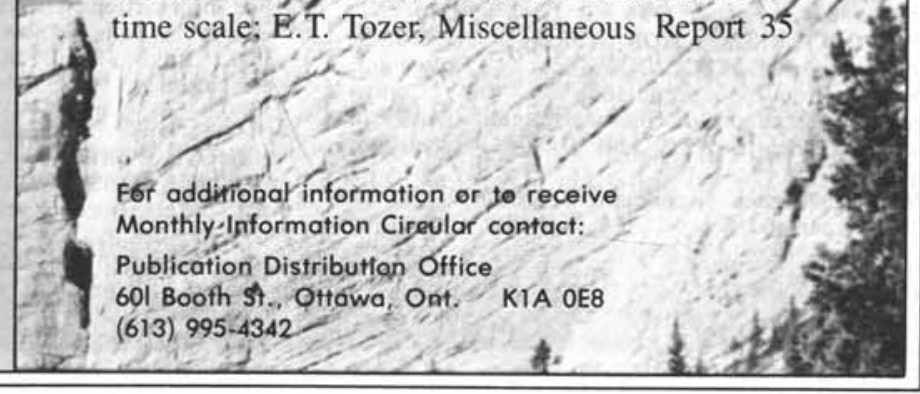